"Harmful mining activities, environmental impacts and effects in the mining communities in South Africa: a critical perspective"

\begin{tabular}{|c|c|}
\hline AUTHORS & $\begin{array}{l}\text { Makua M. Pretty } \\
\text { Kola O. Odeku }\end{array}$ \\
\hline ARTICLE INFO & $\begin{array}{l}\text { Makua M. Pretty and Kola O. Odeku (2017). Harmful mining activities, } \\
\text { environmental impacts and effects in the mining communities in South Africa: a } \\
\text { critical perspective. Environmental Economics, } 8(4), 14-24 \text {. } \\
\text { doi:10.21511/ee.08(4).2017.02 }\end{array}$ \\
\hline DOI & http://dx.doi.org/10.21511/ee.08(4).2017.02 \\
\hline RELEASED ON & Tuesday, 05 December 2017 \\
\hline RECEIVED ON & Sunday, 10 September 2017 \\
\hline \multirow[t]{2}{*}{ ACCEPTED ON } & Friday, 20 October 2017 \\
\hline & $(\mathrm{cc}) \mathbf{E Y - N C}$ \\
\hline LICENSE & $\begin{array}{l}\text { This work is licensed under a Creative Commons Attribution-NonCommercial } 4.0 \\
\text { International License }\end{array}$ \\
\hline JOURNAL & "Environmental Economics" \\
\hline ISSN PRINT & $1998-6041$ \\
\hline ISSN ONLINE & $1998-605 X$ \\
\hline PUBLISHER & LLC "Consulting Publishing Company "Business Perspectives" \\
\hline FOUNDER & LLC "Consulting Publishing Company "Business Perspectives" \\
\hline
\end{tabular}

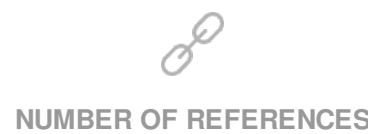

98
NUMBER OF FIGURES

0
ニ:-

NUMBER OF TABLES

0

(C) The author(s) 2022. This publication is an open access article. 
Makua M. Pretty (South Africa), Kola O. Odeku (South Africa)

\title{
Harmful mining activities, environmental impacts and effects in the mining communities in South Africa: a critical perspective
}

\begin{abstract}
In South Africa, the right to a clean environment is constitutionally guaranteed. However, this right is being violated on a daily basis by the mining companies who degrade and harm the environment in the communities they operate. Even though laws have been put in place to regulate, protect and deter degradation, the reality is that the mining companies have been found wanting several times in discharging their constitutional obligations not to degrade and harm the environment. This paper examines impacts and effects of the mining activities. It also looks at the legislative interventions that have been put in place to serve as checks against the mining companies and provides insights on how they are being used to regulate harmful mining practices.
\end{abstract}

Keywords: harmful mining, environmental degradation, mining community, sustainability, regulations, South Africa. JEL Classification: Q56, Q58, L71.

Received on: $10^{\text {th }}$ of September, 2017.

Accepted on: $20^{\text {th }}$ of October, 2017.

\section{Introduction}

In South Africa, the mining industry plays a vital role in the economic growth and development of the country (Hamann, 2003). There are different types of natural mineral resources in South Africa and they serve as a key driver of the country's social economic growth and development (Hamann, 2004). Undoubtedly, mining provides jobs, grows the economy and builds trading relations with the rest of the world. However, when mining is done irresponsibly, it will definitely impact the environment and cause harm and irreparable damages (Bolong, 2016). In South Africa, poor mining operations are costing the country its major asset and resource which is the environment (Downing, 2002). Mining operations usually result in environmental degradation in the mining communities if mine owners do not adhere to regulations that have been put in place to ensure that the environment is not harmed and degraded during these activities (White, 2013). The harm and degradation affect the health and wellbeing of individuals, groups and communities as a result of the toxic environments created by the mining companies. Furthermore, if mining is done irresponsibly, it can devastate local ecosystems and destroy traditional cultures and livelihoods and these are common in many communities in South Africa (Duri, 2016).

(c) Makua M. Pretty, Kola O. Odeku, 2017.

Makua M. Pretty, Faculty of Management and Law, University of Limpopo, Turfloop, South Africa.

Kola O. Odeku, Faculty of Management and Law, University of Limpopo, Turfloop, South Africa.

This is an Open Access article, distributed under the terms of the Creative Commons Attribution-NonCommercial 4.0 International license, which permits re-use, distribution, and reproduction, provided the materials aren't used for commercial purposes and the original work is properly cited.
Sometimes, the impacts are so sever to the extent that a whole community could be deserted thereby creating a 'ghost towns' after the departure of mining company and this is usually the enduring image and legacy of extractive industry (Haney \& Shkaratan, 2003). Therefore, mining has significant social and environmental ramifications directly related to ecological wellbeing and human health (Cullen-Unsworth, 2014). It is against the backdrop of this that the mining companies need to pursue actions that mitigate harmful impacts on the environment while conducting extractive activities (Owen \& Kemp, 2013). There is a need to be mindful of the fact that protection of the natural environment will sustain long-term economic growth. This paper accentuates that the extractions of natural minerals should be done responsibly and sensibly (Mannion, 2014). Against the backdrop of these harmful mining activities resulting in environmental harm, degradation and contamination, this paper discusses the impact of poor mining activities and legislation in place to ensure that mining is done responsibly and sensibly. This is critically imperative in order to protect vulnerable population groups and the communities from environmental harm, degradation and contamination being what resource extraction leave behind and their devastating impacts upon local areas now and into the future (White, 2013).

\section{Problem statement}

Since the late $19^{\text {th }}$ century, South Africa has exploited its mineral wealth with little or no regard for the environment (Death \& Politikon, 2014). From an environmental perspective, South Africa faces several crucial environmental challenges, such as environmental harm, degradation and 
contamination caused by the failure of the mining companies to act responsibly while conducting their business. Yet, to a large extent, the accountability and sanctions of the extractive industry for the impact and consequences of environmental degradation in mining communities has been very poor. Against the backdrop of this irresponsible mining business, communities, ecosystems and the people in the areas they operate are being negatively impacted on a daily basis. Consequently, there is need to understand the extent of damage poor mining operations impacts on the environment and to strengthen compliance and implementation by using the existing laws to hold perpetrators accountable.

\section{Literature review}

Virtually all mining literature attest to the fact that mining should be done in a sustainable way and manner (Danielson, 2006). However, the concern is that "the socio-economic upliftment that should logically follow the implementation of ensuring that mining operation is conduct responsibly is not visible in many mining areas and communities where the mining companies operate" (Ololade \& Annegarn, 2003). The study of Ololade and Annegarn (2003) found out that the environmental and social costs associated with mining were high, while economic benefits to surrounding communities were low". Ololade and Annegarn (2003) also documented that "the perceptions of community and corporations were found to contrast sharply: the reality experienced by community members fell well short of the optimistic scenarios presented in the corporate social responsibility reports of the mining companies, which has implications for the mining industry in the area". Accordingly, for there to be a sustainable mining path, the companies need to change their mind set and stop the business as usual syndrome by altering their operations onto a genuine sustainable path (Ololade \& Annegarn, 2003).

More importantly, Abuya's (2006) work identified mine-related conflicts prevalent in the mining communities such as "land ownership; unfair compensation; inequitable resource distribution; environmental degradation; mine-induced poverty; and conflict over human rights abuses". Conflicts usually occur in the mining communities because the people tend to believe that mine developers will finance tangible projects and services such as schools, hospitals, roads, water and so on but, in most cases, mine companies usually renege on their promises and failed to honor the promises made to the members of the communities (Nkadimeng,
2016). The product of this is the incessant vicious protests which sometimes result to the disruption of mining activities in the community. For there to be a suitable mining, companies must ensure that they fulfill their social responsibility to the community and the environment in order to minimize conflicts (Tello, 2015).

South Africa government has introduced pieces of legislation on the issue of responsible and sensible mining and the protection of the integrity of the environment, however there seems to be poor implementation hence the act of degradation continues (Amechi, 2009). All organs of state must cooperate and work together with regard to ensuring that the environment is protected from harm and degradation. Conversely, for instance, instead of cooperating with the other department to protect the environment from being harmed, the Department of Mineral Resources (DMR) in Mpumalanga, granted prospecting and mining rights even in the face of vehement opposition from other organs of state like conservation and tourism authorities. Mpumalanga is experiencing the worst environmental degradation caused by mining activities in the whole of South Africa as most of its land is no longer conducive for farming, living and there are water pollution and shortage, as well as a result of destructive mining activities. The DMR is also responsible for monitoring the environmental impacts of mining but it is failing dismally at this task. The Department of Environmental and Water Affairs, and local and the district municipalities that have integral role to play in regulation that effectively balances the province's different priorities, are either unwilling or incapable of making a dent in this onslaught (Davies, 2014). The DMR in Mpumalanga generally accepts applications for rights, no matter how sensitive or protected the area in which mining is proposed. For example, Mabola protected environment in the Wakkerstroom is one of the five important water source in Mpumalanga and it was proclaimed protected environment, however Atha-Africa Ventures (Pty) Ltd group, was granted the right to mine coal from the area by DMR despite the opposition of the environmental and water authorities (Cullinan, 2015). This means that the socalled protected area does not enjoy the benefits of being protected. The Minister of Mineral Resources has the power to declare the operation invalid, but has so far refused to do so without a valid reason or communication to the communities affected by the activities.

The permission to mine which was granted to AthaAfrica Ventures (Pty) Ltds a demonstration of the failure of parties involved working together. 
Organizations such as Centre for Environmental Rights and The Mpumalanga Tourism and Parks agency (an organ of state) have called on government to undertake an assessment of the cumulative impacts of mining on the environment. Relevant government departments are also implored to agree to restrictmining in areas which contain critical water sources and biodiversity, or which are important for South Africa's future food security (Davies, 2014).

According to Hassan (2001), "good environmental governance is an important pillar in the global partnership for sustainable development". Environmental governance may be described "as the manner in which people exercise authority over nature (Hassan, 2001)". It is pertinent to mention that "natural resource management was internationalized by the 1972 Stockholm Declaration 2004, echoing the earlier internationalization of human rights by the 1948 Universal Declaration of Human Rights (UDHR) UN General Assembly in Paris 10 December 1948" (Hassan, 2001). The concept of human right to a healthy environment developed from the first principle of the Stockholm Declaration which states that "man has the fundamental right to freedom, equality and permits a life of dignity and well-being, and he bears a solemn responsibility to protect and improve the environment for present and future generations" (Stockholm Declaration Principle 1).

The Stockholm Declaration does not specify the right to a healthy environment, as such, but it does claim the right to adequate conditions of life in a temporal perspective to safeguard the environment for future generations (Hiskes, 2012). It follows that a healthy environment is necessary for the appreciation of other human rights (Lewis, 2013). Section 24 of the South African Constitution embodies the right to a healthy environment and to conservation of the environment.

Good environmental governance would begin with a democratic dispensation that allows full participation of civil society in the running and administration of its affairs (Hassan, 2001). Such a dispensation enables national and provincial legislatures to respond to the emerging needs of society for general and specific regimes and laws for environmental protection and sustainable development (Van Rensburg \& Naude, 2007). In order to protect the environment from being harmed and degraded, there must be strong willingness to ensure effective and efficient management and as such, according to Hassan (2001), "legislation is a major tool for achieving good environmental management, rule of law, respect for human rights and a free and independent judiciary are essential for protecting and enforcing environmental protection regimes" (Hassan, 2001). The question is whether mining companies are adhering to the elements of good environment governance with respect to mitigation of the adverse effects of mining activities on local communities (Truter, 2011). The court in South Africa had pronounced on the need for ensuring the proper protection of the environment while pursuing socio-economic activities or mining as adumbrated in the case of Fuel Retailers Association of Southern Africa $v$ Director-General: Environmental Management, Department of Agriculture, Conservation and Environment, Mpumalanga Province and Others (CCT67/06) [2007] ZACC 13; 2007 (10) BCLR 1059 (CC); 2007 (6) SA 4 (CC) (7 June 2007) where the constitutional court held that "the essence of sustainable development is balanced integration of socio-economic development and environmental priorities and norms. Economic sustainability is thus not part of a check-list that has to be ticked off as a separate item in the sustainable development enquiry. Rather, it is an element that takes on significance to the extent that it implicates the environment. When economic development potentially threatens the environment it becomes relevant to NEMA. Only then does it become a material ingredient to be put in the scales of a NEMA evaluation". This paper seek to show that some of the mining companies are not adhering to good government in their operations and as such they should be sanctioned using existing legislation that talk to the issues of protection of the environment even when conducting extractive activities.

\section{The impacts and effects of mining on the community they operate}

The awful living conditions of mine-affected communities and the shocking failure of mining companies to meaningfully or positively engage with them are clear testimony to irresponsible mining activities (Sarkar et al., 2010). The devastating impact of mining on land; the impact of air, water and soil pollution on farming activities and human health; mining companies' poor compliance with legal and regulatory requirements for environmental protection (Bridge, 2004). The almost total lack of compliance monitoring and enforcement by the Department of Mineral resources and the "extremely cavalier attitude of the South African mining industry towards the closure of mines and the rehabilitation of the environment is what causes these small communities to suffer the 
fate imposed upon them by the mining companies" (Bench Marks Foundation: Policy Gap 9 South African coal mining, August 2014). The impacts and effects of poor and harmful mining activities are numerous and some are discussed below.

3.1. Impact and effect of harmful mining. Bad mining practices can ignite fires which can burn for decades, releasing fly ash and smoke laden with greenhouse gasses and toxic chemicals (Dontala et al., 2015). Harmful dust inhalation causes black lung disease among miners and those who live nearby, and mine accidents kill thousands every year (Eisler, 2003). Harmful mining could displace whole communities, forcing them off their land due to expanding mines, fires, subsidence and contaminated water supplies (Goswami, 2014).

In some cases, the environment will be toxic to the extent that people in the communities are forced to evacuate their homes as the conditions of the degraded environment and land worsen (Warner et al., 2010). Their livestocks die and they are not able to grow crops on the land (Yu et al., 2011). Ground water decreases and rivers dry up and the cloud of black dust lingers in the chemically polluted air and the noise from the huge trucks and the blasting (Joseph, 2005). Sometimes, even relocating the community to another location does not deter the impact of mining, especially if the new location is still in close proximity to the mining area (Gupta \& Lehal, 2009). For example, Mmadithlokwa village located in Marikana was relocated by Tharisa Minerals just a few kilometers from the mining operations and now the community is negatively impacted by these mining activities, some residents are relocating from the chosen area as they no longer feel safe (Tunatazama, 2017). Those who are too poor to rebuild their homes have remained because they have no other option, the mine requires prove that indeed the dilapidation of the houses are caused by the mining activities and the residents have nothing to show except for their cracked houses which are not enough for the company to carry the responsibility of relocating them. This problem can be avoided by proper communication with the communities and relocation of the community to newly developed areas distant from the mining area.

3.2. Strip mining. There are two widely used ways of mining: strip mining and underground mining. Strip mining (also known as open cast, mountaintop or surface mining) involves scraping away earth and rocks to get to coal buried near the surface (Montrie, 2001). In many cases, mountains are literally blasted apart to reach thin mineral seams within, leaving permanent scars on the landscape (Dontala et al.,
2017). Even though it is highly destructive, industries often prefers this methods it requires less labour and yields more mineral-coal than underground mining. Underground mining will require the input of engineers to ensure that it is safe for mineworkers to go underground to extract the resource.

3.2.1. Impacts of strip mining. Strip mining destroys landscapes, forests and wildlife habitats at the site of the mine when trees, plants, and topsoil are cleared from the mining area (Brennan et al., 2005). This in turn leads to soil erosion and destruction of agricultural land. Rain can wash the loosened top soil into streams that becomes sediments polluting waterways which can hurt fish and smother plant life downstream. It also causes disfiguration of river channels (Maya, 2014). There is also an increased risk of chemical contamination of ground water when minerals in upturned earth seep into the water table, and watersheds are destroyed when disfigured land loses the water it once held (Witze \& Kanipe, 2015). Strip mining causes dust and noise pollution when top soil is disrupted with heavy machinery and coal dust is created in mines (Igoe, 2014). The result of all this is barren land that stays contaminated long after a mine shuts down (Rai, 2015).

Although legal regulations can be used to ensure that the land is rehabilitated and restored, as well to enforce compliance of the other processes of restoration of the land, undoing all the environmental damages to water supplies, destroyed habitats, and poor air quality is a long and problematic task (Davies, 2014). Oftentimes the land degraded is vast. For example, in Emalahleni, Witbank, coal mining has degraded the quality of an estimated 3.2 million hectares of land.The overall restoration rate (the ratio of reclaimed land area to the total degraded land area) of mine wasteland was only about 10-12 percent (Johnson \& Hallberg, 2005).

3.3. Underground mining. Underground miningallows mining companies to extract deeper deposits of mineral resource and this is viewed as less destructive than strip mining. Nevertheless, it still causes widespread damage to the environment. In room-and-pillar mines, columns of coal used as pillars are left to support the ground above during the initial mining process, then they are often taken out and the mine is left to collapse, which is known as subsidence. For instance, Lannex mine in Eerstegeluk, Steelpoort just outside of Burgersfortin South Africa experienced one of the most frightening moments in the area when a mountain sunk in while the community watched in fear. This according to reports was due to the collapse of 
pillars that help to keep the table rock intact and possible for mine workers to work underground (Motseo, 2013).

3.4. Common health threats posed by mining. Pneumoconiosis, also known as the black lung disease or coal worker's pneumoconiosis (CWP), common in miners is caused by breathing in coal dust and carbon, which harden the lungs (Dontala et al., 2015). Cardiopulmonary disease, chronic obstructive pulmonary disease, hypertension, lung disease, and kidney disease have been found in higher-than-normal rates among residents who live near coal mines (Hendry \& Ahem, 2008). In Witbank, there have been reports that the residents suffer from the black lung disease caused by inhaling the air infested with the residue dust from the coal.

\section{Prohibition of environmental degradation in the mining communities}

South Africa has numerous environmental laws and policies in place which are frequently amended for effective and efficient management and protection of the environment (Fuggle \& Rabie, 2009). Some of these are discussed below.

4.1. Mineral Act 50 of 1991. The Mineral Act 50 of 1991 (MA) came into force on 1 January 1992. The goal of the MA was to achieve uniform regulation of minerals. As opposed to the previous system of regulatory control through conferral of rights. The MA aimed to achieve the regulatory objectives of the state by imposing a system of authorization. It simplified the complex multiplicity of the prospecting, mining and surface right forms that had existed before its commencement. It also consolidated the rules regarding the exercise of mineral rights and those regarding the achievement of prescribed health and safety standards. Furthermore, it dealt with rehabilitation, surface use and acquisition of land and payment of compensation in respect to open-cast mining operations, as well as underground mining operations and prospecting or mineral recovery operations in respect of tailings (Ashton et al., 2001). All pre-existing classification of minerals became irrelevant with the introduction of the MA. The Act referred to minerals and land in uniform fashion. The MA pursued a trinity of objectives, namely (i) optimal utilization of country's mineral resources; (ii) mining safety and health; and (iii) rehabilitation. It was the task of government to regulate the prospecting, optimal exploitation, processing and utilization of miners and to ensure rehabilitation of the land and safe mining practices. Its stated purpose was to ensure adherence to these principles by imposing a system of authorizations. Thereafter, only three different forms of authorizations namely prospecting permits, mining permits and mining licenses existed.

This constituted a significant reorientation of the previous dispensation, which acknowledged about 40 types of permits, licenses, concessions and so on. No person could prospect for minerals without having been granted the necessary authorization in accordance with the section 5(2) of MA. The applicant had to provide proof of the right to the mineral and had to comply with certain environmental requirements pertaining to rehabilitation of surface disturbances and the ability to rehabilitate such disturbances. The applicant also had to demonstrate the ability to prospect in a healthy and safe manner to the satisfaction of the Chief Inspector of Mines.

One of the aims of the MA was surface rehabilitation. Accordingly, the Act placed a particular focus on environmental regulation, and the system of authorizations operated to support the goal of surface rehabilitation in terms of subsection 38 to 42 , read where appropriate with section 9 of the MA. Initially these provisions were supplemented by regulations in terms of Mines and Works Act 27 of 1956 which remained intact until more stringent and adequate programs were promulgated to replace them in 1993 . The ability to rehabilitate is relevant for applications of mining rights. Rehabilitation was a factor considered in determining whether additional prospecting permits on mining authorizations could be issued in respect of land permits or authorizations that had already been issued. Moreover, non-compliance with the rehabilitation duties will result in the compulsory suspension or cancellation of the prospecting permit or authorization.

The rehabilitation provisions in the MA exhaustively regulated the discretion of the officials assigned with considering applications for prospecting permits and mining authorizations to make environmentally sound decisions.

4.2. The Constitution of the Republic of South Africa, 1996. The Constitution of South Africa supports the initiative to protect and preserve the environment and life. It states that everyone has the right- to an environment that is not harmful to their health or wellbeing (section 24(a)). To have the environment protected, for the benefit of present and future generations, (section 24(b)(i)) of the constitution promotes conservation; section 24(b)(ii)); secures ecologically sustainable development and use of natural resources while 
promoting justifiable economic and social development. The Constitution is the supreme law of the country and as such it promotes the right to clean environment and the government and its institutions have obligations to protect, prevent and promote this right.

4.3. National Environmental Management Act 107 of 1998 (NEMA). The purpose of this Act is to provide for co-operative and environmental governance by establishing principles for decisionmaking on matters affecting the environment and institutions that will promote co-operative governance and procedures for co-coordinating environmental functions exercised by organs of state; and to provide for matters connected therewith in terms of section 12 of NEMA. NEMA also provides for implementation and management plans and the purposes are to (a) co-ordinate and harmonize the environmental policies, plans, programmes and decisions of the various national departments that exercise functions that may affect the environment or are entrusted with powers and duties aimed at the achievement and promotion of clean environment in terms of section 12 (1) (a) of NEMA. To protect the sustainable environment, and the provincial and local spheres of government, in order to (i) minimize the duplication of procedures and functions; and (ii) promote consistency in the exercise of functions that may affect the environment (section 12 (1)(a)(i) \&(ii)); (b) give effect to the principle of co-operative government in Chapter 3 of the Constitution (section 12 (1)(a)(ii)); (c) secure the protection of the environment across the country as a whole (section 12 (1)(a)(ii).): (d) prevent unreasonable actions by provinces in respect of the environment that are prejudicial to the economic or health interests of other provinces orthe country as a whole (section 12 (1)(a)); and (e) enable the Minister to monitor the achievement, promotion, and protection of a sustainable environment (section 12(1)(a)). The South African Constitutional court has however warned that the submission of environmental management plan is not enough thus in the case of Bengwenyama Minerals (Pty) Ltd and Others $v$ Genorah Resources (Pty) Ltd and Others (CCT 39/10) [2010] ZACC 26; 2011 (4) SA 113 (CC); 2011 (3) BCLR 229 (CC) (30 November 2010). Para 77, the Constitutional court held that “....an applicant who applies for the granting of a prospecting right needs to submit an environmental management plan(not a programme), and secondly because the section explicitly states that the granting of the prospecting right only becomes-effective on approval of the program. It obviously relates to the implementation of the prospecting operation, not its approval. Approval of the prospecting operation is dependent on an assessment that the operation will not result in unacceptable pollution, ecological degradation or damage to the environment".

Many inhabitants in the mining communities in South Africa live in an environment that is harmful to their health and well-being (McDonald, 2004), as a result of environmentally harmful practices. These practices are contrary to section 24(1) (b) of the Constitution which provides that everyone has the right to an environment that is not harmful to his or her health or well-being. Section 24 also talks about sustainable development wherein development should take into consideration the protection of the environment. To this end, sustainable mining will entail the integration of social, economic and environmental factors in the planning, implementation and evaluation of decisions to ensure that development serves present and future generations.

Sustainable development requires the consideration of all relevant factors in the course of any business particularly mining and the mining operators must ensure that the disturbance of ecosystems and loss of biological diversity are avoided, or, where they cannot be altogether avoided, are minimized and remedied (section 4(a) of NEMA). That pollution and degradation of the environment are avoided, or, where they cannot be altogether avoided, are minimized and remedied; that the disturbance of landscapes and sites that constitute the nation's cultural heritage is avoided, or where it cannot be altogether avoided, is minimized and remedied. Adhering to these principles will definitely promote and produce sustainable mining business. However if there is transgression of the principles and the law, the law should be enforced by the State against erring mining company. It is against the backdrop of this that the court in the case of Fuel Retailers Association of Southern Africa $v$ Director-General: Environmental Management, Department of Agriculture, Conservation and Environment, Mpumalanga Province and Others (CCT67/06) [2007] ZACC 13; 2007 (10) BCLR 1059 (CC); 2007 (6) SA 4 (CC) (7 June 2007) held that sustainable economic and mining development are elements that take "on significance to the extent that they implicate the environment and that when economic development such as harmful mining potentially threatens the environment it becomes relevant to NEMA and this threat will automatically become a material ingredient to be put in the scales of a NEMA evaluation in order to ascertain the extent of contravention and the necessary sanctions to be imposed accordingly. 
4.4. Mineral and Petroleum Resources Development Act 2002. One of the objectives of this Act is to give effect to section 24 of the Constitution by ensuring that the nation's mineral and petroleum resources are developed in an orderly and ecologically sustainable manner while promoting justifiable social and economic development. A prospecting right, mining right, exploration right or production right granted in terms of this Act is a limited right in respect of the mineral or petroleum and the land to which such right relates.

No person may prospect for, mine, conduct technical co-operation operations, reconnaissance operations, explore for and produce any mineral or petroleum or commence with any work incidental thereto on any area without an approved environmental management plan, as the case may be and consulting with the land owner or lawful occupier of the land in question.

If any prospecting, mining, reconnaissance or production operations cause or results in ecological degradation, pollution or environmental damage which may be harmful to the health or well-being of anyone and requires urgent remedial measures, the Minister may direct the holder of the relevant right, permit or permission to investigate, evaluate, assess and report on the impact of any pollution or ecological degradation.

If the holder fails to comply with the directive, the Minister may take such measures as may be necessary to protect the health and well-being of any affected person or to remedy ecological degradation and to stop pollution of the environment. If the minister directs that measures contemplated in section 45 must be taken to prevent pollution or ecological degradation of the environment or to rehabilitate dangerous occurrences but establishes that the holder of the relevant reconnaissance permission, prospecting right, mining right, retention permit or mining permit, as the case may be, or his or her successor in title, is deceased or cannot be traced or, in the case of a juristic person, has ceased to exist, has been liquidated or cannot raced, the Minister may instruct the Regional Manager concerned to take the necessary measures to prevent further pollution or degradation, or make the area safe.

The measures contemplated in subsection (1) must be funded from the financial provisions made by the holder of the relevant rights, where necessary appropriate, or if there is no such provision or if it is inadequate, from money appropriated by the Parliament for the purpose. Upon completion of the measures contemplated in subsection (1), the Regional Manager must apply to the registrar concerned that the title deed of the land in question be endorsed to the effect that such land had been remedied. The registrar concerned must, on receipt of the application contemplated in paragraph (a) make such endorsements as he or she may deem necessary so as to give effect to provisions of that paragraph, and no office fee or other charge is payable to the registrar in respect of such endorsement.

The MPRDA is the backbone of the mining legislation as it provides for the negotiation stages, prospecting stages, closure and rehabilitation and restoration of the land prior, during and after the mining activities. This Act gives the Minister the power to intervene to prevent environmental degradation and where necessary revoke a mining right to protect and minimize environmental degradation.

The Environmental Management Program is a section 39 requirement of the MPRDA and can be used to address all the legal requirements (in short referred to as the section 39 EMPR). Updates with regards to the legal requirements are addressed through the annual updates required under Regulation 55 of the MPRDA. The changes made in the statute will result in a change of this mechanism.

The statute deals with the responsibilities of holders of mining rights, permits, or permissions and states in section 38(1)(e) that such holder, whose mining causes or results in ecological degradation, pollution, or environmental damage that may be harmful to the health or well-being of anyone", is responsible for any environmental damage, pollution or ecological degradation as a result of his or her operations and which may occur inside and outside the boundaries of the area to which such right, permit or permission relates", and in terms of section 43(1), "remain responsible for any environmental liability, pollution or ecological degradation and the management thereof until a closure certificate has been issued". The Minister only issues the certificate after he is completely satisfied that the holder of the right has adhered to the regulations provided in the EMP and the EMPR. If he is not satisfied then the holder of the right will be held liable. If this regulation is stringently enforced, it can reduce any further degradation to the mining area as the holder will have to restore the land to its state before the mining activities.

4.5. National Environmental Management: Biodiversity Act No. 10 of 2004. The Biodiversity Act is fundamental to the notion of sustainable 
development. International guidelines and commitments as well as national policies and strategies are important in creating a shared vision for sustainable development in South Africa (MMSD, 2014).

The function of the South African National Biodiversity Institute is established by this Act, The institute may coordinate and implement programmes for the rehabilitation of ecosystems and the prevention, control or eradication of listed invasive species. The institute may also coordinate programmes to involve civil society in the conservation and rehabilitation of the ecosystem.

This act protects areas where endangered species can be found. It protects against environmental degradation and promotes rehabilitation where prevention cannot be possible. For example, if there are minerals on a land where endangered species are found and cannot be rescued or relocated, then such mining right for that particular area will not be granted.

\section{Conclusion}

The extent of the effects of mining activities on the communities in South Africa is appalling and as such efforts must be made to protect the environment from harmful mining operations that degrade the communities where they operate. To this end, the extractive companies should operate responsibly and sensibly as this will promote sustainable mining activities. However, if they do not, there are ample legislation in South Africa that could be used to make them accountable and responsible as articulated in this paper. The court should continue to play its judicial role to protect the environment by interpreting salient provisions in the legislation and apply them to sanction erring mining companies.

\section{References}

1. Agius, J. (2009). International Environmental Law and State Sovereignty. Asia Pacific Journal of Environmental, 26.

2. Ajei, M. O. (2007). Africa's Development: the imperatives of indigenous knowledge and values.

3. Akcil, A., \& Koldas, S. (2006). Acid Mine Drainage (AMD): causes, treatment and case studies. Journal of Cleaner Production, 1139-1145.

4. Allan, R. J. (1995). Impact of mining activities on the terrestrial and aquatic environment with emphasis on mitigation and remedial measures.

5. Amechi, E. P., Law Env't, \& Dev, J. (2009). Poverty, Socio-Political Factors and Degradation of the Environment in Sub-Saharan Africa: The Need for a Holistic Approach to the Protection of the Environment and Realisation of the Right to Environment. from http://heinonline.org/HOL/LandingPage?handle=hein.journals/leadjo5\&div=11\&id=\&page (accessed on June 12, 2016).

6. Ashton, P., Love, D., Mahachi, H., \& Dirks, P. (2001). Overiew of the impact of mining and mineral processing operations on water resources and water quality in the Zambezi, Limpopo and Olifants catchments in Southern Africa (accessed on August 10, 2017.)

7. Atha-Africa Ventures (Pty) Ltd (A-AV) is a subsidiary of Atha Group, India, and is the flagship Company of the Group in South Africa. AAV has a registered office in Sandton, Johannesburg, with a dedicated team. Retrieved from http://heinonline.org/HOL/LandingPage?handle=hein.journals/apjel6\&div=3\&id=\&page (accessed on May 15, 2016).

8. Ayres, T. (2015). Legal Requirements. The Environmental Management Programme (EMP): A Critique.

9. Badenhorst, P. J., Schoeman's. (2006). The Law of Property $\left(5^{\text {th }}\right.$ ed.).

10. Bell, D. T., \& Heddle, E. M. (1989). Floristic, morphologic and vegetational diversity. In The Jarrah Forest: A Complex Mediterranean Ecosystem (pp. 53-66).

11. Bell, F. G. (2000). Environmental impacts associated with an abandoned mine in the Witbank Coalfield, South Africa. International Journal of Coal Geology, 195-216.

12. Bell, F. G., Bullock, S. E. T., Halbich, T. F. J., Lindsay, P. (2001). Environmental impacts associated with an abandoned mine in the Witbank Coalfield, South Africa. International Journal of Coal Geology, 195-216.

13. Bell, F. G., Stacey, T. R., Genske, D. D. (2000). Mining subsidence and its effect on the environment: some differing examples.

14. Bench Marks Foundation (2014). Policy Gap 9. South African coal mining, August 2014.

15. Bobbin, K. (2015). Acid Mine Drainage and its Governance in the Gauteng City-Region. Occasional Paper for the GCRO.

16. Bolong, L. D. O., Tul. J. Int'l, \& Comp, L. (2016). Into The Abyss: Rationalizing Commercial Deep Seabed Mining Through Pragmatism and International Law. Retrieved http://heinonline.org/HOL/LandingPage?handle=hein.journals/tulicl25\&div=8\&id=\&page (accessed on June 16, 2017).

17. Brennan, K. F. C., Nicholas, O. G., \& Majer, J. D. (2005). Innovative techniques for promoting fauna return to rehabilitated sites following mining.

18. Bridge, G. (2004). Contested terrain: mining and the environment. Retrieved from http://www.annualreviews.org/doi/abs/10.1146/annurev.energy.28.011503.163434 (accessed on May 17, 2017). 
19. Cahill, D. M., Rookes, J. E., Wilson, B. A., Gibson, L. (2008). Phytophthoracinnamomi and Australia's biodiversity: impacts, predictions and progress towards control.

20. Colquhoun, I. J., \& St. Hardy, G. E. (2000). Managing the risks of Phytophthoraroot and collar rot during bauxite mining in the Eucalyptus marginata (Jarrah) forest of Western Australia. Plant Disease, 84, 116127 (accessed on November 16, 2016).

21. Cullen-Unsworth, L. C., Nordlund, L. M., Paddock, J. (2014). Seagrass meadows globally as a coupled social ecological system: Implications for human wellbeing, Marine Pollution. Retrieved from http://www.sciencedirect.com/science/article/pii/S0025326X13002919 (accessed on June 9,2016).

22. Cullinan, K. (2015). Health E-News: Mining- the fox is in charge of the hen house. Daily Maverick, 18 October 2015.

23. Danielson, L. (2006). Architecture for change: An account of the mining, minerals and sustainable development project. Berlin, Global Public Policy Institute. Retrieved fromhttp://www.gppi.net/ (accessed on May 4, 2016).

24. Davies, T. (2014). A desperate battle is raging across vast tracts of Mpumalanga between coal mining on the one hand and water preservation, food security and tourism on the other, 15 September 2014.

25. Davies, T. (2014). Environmental crisis in Mpumalanga: why is nobody listening? 15 September 2014. Centre for Environmental Rights.

26. Death, C. (2014). The green economy in South Africa: Global discourses and local politics. Retrieved from http://www.tandfonline.com/doi/abs/10.1080/02589346.2014.885668 (accessed on August 17,2016).

27. Dontala, S. P., Reddy, T. B., Vadde, R. (2015) Environmental aspects and impacts its mitigation measures of corporate coal mining. Retrieved from http://www.sciencedirect.com/science/article/pii/S1878522015000533 (accessed on July 17, 2016).

28. Downing, T. E. (2002). Avoiding new poverty: mining-induced displacement and resettlement. Retrieved from http://pubs.iied.org/pdfs/G00549.pdf (accessed on February 4,2017).

29. Duri, F. T. P. (2016). Chapter Fifteen Environmental Activism from Below: The Case of the subaltern against Commercial Diamond-mining Companies in the Chiadzwa Area of Zimbabwe. Retrieved from https://books.google.co.za/books?hl=en\&lr=\&id=1fXMDQAAQBAJ\&oi=fnd\&pg=PA415\&dquxfTQluojs\&sig=8 1NC 6y4iRrZQahY6mT433HufBFc\#v=onepage\&q\&f=false (accessed on May 19,2017$)$.

30. Eisler, R. (2003). Health risks of gold miners: a synoptic review-Environmental Geochemistry and Health. Retrieved fromhttps://link.springer.com/article/10.1023\%2FA\%3A1024573701073?LI=true (accessed on June 17, 2016).

31. Ferris, L., \& Kotze, L. J. (2014). The Regulations of Acid Mine Drainage in South Africa: Law and Governance Perspectives. PER/PELJ 2105.

32. Fuggle, R. F., Rabie, M. A. (2009) Environmental Management in South Africa. Retrieved from https://books.google.co.za/books?hl=en\&lr=\&id=pyctQBW8fZUC\&oi=fnd\&pg=PR5\&dq=ey6JeaMJ7C\&sig=CP Z3cq kEsCChcEEZaibK9sxqEg\#v=onepage\&q\&f=false (accessed on July 27,2016).

33. Gao, L., Miao, Z., Bai, Z., Zhou, X., Zhao, J., Zhu, Y. (1998). A case study of ecological restoration at the Xiaoyi Bauxite Mine, Shanxi Province. China1, 1997. Ecological Engineering.

34. Gao, L., Miao, Z., Bai, Z., Zhou, X., Zhao, X., Zhu, Y. (1995). Reclamation of mining land in China: Policies and practices In Wang, R. (Ed.)., Wealth, Health and Faith. China Environmental Science (pp. 130-141.)

35. Gardner, J. H., \& Bell, D. T. (2007). Bauxite mining restoration by Alcoa World Alumina Australia in Western Australia: social, political, historical, and environmental contexts.

36. Goswami, S. (2014). Environmental Impact Assessment of Coal Mining: Indian Scenario. Retrieved from https://elibrary.ru/item.asp?id=22006298 (accessed on May 17,2017).

37. Grant, C., \& Koch, J. (2007). Decommissioning Western Australia's First Bauxite Mine: Co-evolving vegetation restoration techniques and targets.

38. Gupta, V., Lehal, G. S. (2009). A survey of text mining techniques and applications.

39. Hamann, H. (2004). Corporate social responsibility, partnerships, and institutional change: The case of mining companies in South Africa.

40. Hamann, R. (2003). Mining companies' role in sustainable development: the'why'and'how'of corporate social responsibility from a business perspective. Retrieved from http://www.tandfonline.com/doi/abs/10.1080/03768350302957 (accessed on July 17,2016).

41. Hamann, R. (2004). Corporate social responsibility, partnerships, and institutional change: The case of mining companies in South Africa. Retrieved from http://onlinelibrary.wiley.com/doi/10.1111/j.14778947.2004.00101.x/full (accessed on July 27,2017).

42. Haney, M., Shkaratan, M. (2003). Mine Closure and its Impact on the Community.

43. Harmony Gold mining company Ltd v Regional Director: Free State Department of Water Affairs \& others 2014(3) SA 149 (SCA).

44. Hassan, P. (2007). Environmental Protection, Rule of Law and the Judicial Crisis in Pakistan, 2007. Asia Pacific Journal of Environmental Law, 167.

45. Hendry, M., \& Ahem, M. (2008). Relations between Health Indicators and Residential Proximity to Coal Mining in West Virginia.

46. Herbert, T. L. (2000). The Impact of Environmental Protection on the Acquisition, Transfer and Renewal of Mineral Rights (LLB thesis, University of Cape Town). Retrieved from www.landlawwatch.co.za (accessed on June 15, 2016).

47. Hilson, G., Murck, B. (2000). Sustainable development in the mining industry: clarifying the corporate perspective 
(accessed on December 19,2016).

48. Hiskes, R. P. (2012). Environmental Human Rights: Handbook of Human Rights. Retrieved from https://books.google.co.za/books?hl=en\&lr=\&id= zt9AgAAQBAJ\&oi=fnd\&pg=PA399\&dq=wNQ162vPU8\&sig $=$ Vh1 udFZprrYcQXpAzwDneBExX-0\#v=onepage \&q\&f=false (accessed on June 23,2017).

49. Horn, L. (2004). The implications of the concept of common concern of a human kind on a Human Right to a healthy environment. Macquarie Journal of International and Comparative Environmental Law, 233.

50. Humby, T. (2012). Maccsand: Intergovernmental relations and the doctrine of usurpation, 27(2) SA Public Law (pp. 628-638).

51. Ibe, E. E. (2015). Perception of Nigerians on the negative impact of electricity generation on the environment in Nigeria. Retrieved from http://www.environment.co.za/mining-2/effects-of-mining.html (accessed on May 29,2016).

52. Igoe, L. T. (2014). The opulent city and the Sylvan state: Art and environmental embodiment in early national Philadelphia.

53. Jeffrey, M. (2005). Environmental ethics and sustainable development: Ethical and Human Rights issues in implementing indigenous rights. Macquarie Journal of International and Comparative Environmental Law, 105.

54. Johnson, D. B., \& Hallberg, K. B. (2005). Acid mine drainage remediation options: review.

55. Johnson, M. S., Putwain, P. D. (1981). Restoration of native biotic communities on land disturbed by metalliferous mining.

56. Joseph,

B.

(2005).

Environmental

studies.

Retrieved

from https://books.google.co.za/books?hl=en\&lr=\&id=tuH8cujFqnIC\&oi=fnd\&pg=PR15\&dq=\&ots=LzK4DZFFSd\&si $\mathrm{g}=\mathrm{H}$ LpwsMcMaFzKfgKoeoA6buwvy-Q\#v=onepage\&q\&f=false (accessed on May 17,2016).

57. Lalor, B. M. (2008). An assessment of the recovery of the microbial community in Jarrah forest soils after Bauxite mining and prescription burning.

58. Lewis, B. (2013). Environmental rights or a right to the environment? Exploring the nexus between Human Rights and Environmental protection. Macquarie Journal ofInternational and Comparative Environmental Law, 97.

59. Li, W. (2004). Degradation and restoration of forest ecosystems in China.

60. Liu, R. (1995). Review of reclamation of waste land in China. Reclamation and Greening of Waste Land of Mine, 1-6.

61. Livesley, K. (2010). Mine rehabilitation in the Australian minerals industry.

62. Livesley, S. (2016). Conserving herbivorous and predatory insects in urban green spaces.

63. Ma, Z. (1995). Research on Reclamation of Surface-Mined Lands in the Loess Plateau ( $1^{\text {st }}$ ed.). Scientific Press, Beijing, 199.

64. Mahalu, C. R. (1989). Environmental Degradation and The Law in Tanzania. Retrieved from http://www.jstor.org/stable/43109907 (accessed on 19 December, 2016).

65. Mannion, A. (2014) Global environmental change: a natural and cultural environmental history. Retrieved from https://books.google.co.za/books?hl=en\&lr=\&id=k1SPBAAAQBAJ\&oi=fnd\&pg=PP1\&dq=fJssm5Gz_u\&sig=R2vN FFyRcBkZzFA_LtI4G3RmXsg (accessed on June 6, 2017).

66. McCarthy, T. S. (2001). The impact of acid mine drainage in South Africa. South African Journal of Science, 712.

67. McDonald, D. A. (2004). Environmental Justice in South Africa. Retrieved from https://books.google.co.za/books?hl=en\&lr=\&id=F1WdPPD15pYC\&oi=fnd\&pg=PR9\&dq (accessed on August 17, 2016).

68. Mehta, M. C. (1997). Making the Law Work for the Environment. Asia Pacific Journal of Environmental Law, 349.

69. Miao, Z. W., Gao, L., Zhang, W. (2002). Ecological rebuilding and land reclamation in surface mines in Shanxi Province, China.

70. MMSD (2014). Such as the Johannesburg Plan of Implementation, agreed at the World Summit on Sustainable Development in 2002, the Mining, Minerals and Sustainable Development (MMSD) reports and the National Strategy for Sustainable Development (2011-2014).

71. Montrie, C. (2001). To save the land and people: a history of opposition to coal surface mining in Appalachia.

72. Motseo, G. (2013). A mountain caves in, Lannex. Steelburger local newspaper September 2013.

73. Neate, G. (2001). Review of conference: emerging issues and future directions.

74. Nkadimeng, M. J. (2016). The Driekop community's perception of the impact of the Modikwa platinum mine. Retrieved from http://wiredspace.wits.ac.za/handle/10539/21488 (accessed on January 6, 2017)

75. Norman, M. A., Koch, J. M., Grant, C. D., Morald, T. K. (2006). Vegetation Succession after Bauxite Mining in Western Australia.

76. Obama, B., Senator, U. S. (2013). Coal, Natural Gas, Tar Sands: More Greenhouse Gases at Higher Cost, The Coming Storm.

77. Ololade, O. O., Annegarn, H. J. (2016). Mining conflicts and Corporate Social Responsibility: Titanium mining in Kwale, Kenya. The Extractive Industries and Society, 3(6), 485-493. Retrieved from http://www.sciencedirect.com/science/article/pii/S0301420713000767 (accessed on April 29,2016).

78. Owen, J. R., Kemp, D. (2013). Social licence and mining: A critical perspective.

79. Paczkowska, G., \& Chapman, A. R. (2000). The Western Australian Flora. A Descriptive Catalogue.

80. Padmalal, D., Maya K. (2014). Impacts of river sand mining.

81. Pfeiffer, J. W. (1999). Conditions that hinder effective communication.

82. Pinetown, K. L., Ward, C. R., \& Van Der Weisthuisen, W. A. (2005). Quantitative evaluation of Mineral in coal deposits 
in the Witbank and Highveld coalfields, and the potential impact on acid mine drainage.

83. Rai, V. R., Raman, N. S., Choudhary, S. K. (2015). Development of Indian Coal Industry Specific Environment Audit Format.

84. Ramanujan, K. (2005). Methane's Impacts on Climate Change May Be Twice Previous Estimates, Goddard Space Flight Center, July 18, 2005.

85. Robert, E. D. (1992). Prime Farmland Reclamation. In Dept. Agronomy, IL Agric. Experiment Station (p. 184). University of Illinois Press, Urbana.

86. Schmitz, J. A. (2005). What determines productivity? Lessons from the dramatic recovery of the US and Canadian iron ore industries following their early 1980 s crisis.

87. Schultz, J. (1999). Balancing the Relationship between Trade and the Environment within the World Trade Organization: Is the End of the Sea Turtle? Asia Pacific Journal of Environmental, 37.

88. Stockholm Declaration (2004). Declaration of the United Nations Conference on the Human Environment (Stockholm) UN Doc A/CONF/48/14/REV.1 ("Stockholm Declaration").

89. Stracher, G. B., Taylor, T. P. (2004). Coal fires burning out of control around the world: thermodynamic recipe for environmental catastrophe. International Journal of Coal Geology. Retrieved from http://www.sciencedirect.com/science/article/pii/S0166516204000102 (accessed on February 5,2016).

90. Tello, R. (2015) Social Safeguards: Avoiding the Unintended Impacts of Development. Retrieved from https://books.google.co.za/books?hl=en\&lr=\&id=q1QrDwAAQBAJ\&oi=fnd\&pg=PA7\&dq=fE23z6TZNH\&sig=L JCD 7AEmJbHYDbxCU391q64FQXY\#v=onepage\&q\&f=false (accessed on May 15,2017).

91. Truter, J. (2011). Mining rehabilitation- a regulated activity- natural resources.

92. Truter, J. (2016). South Africa. Mining Rehabilitation-A regulated activity. Werksmans incorporated (accessed on August 15, 2017).

93. Van Rensburg, L. J., Naudé, W. (2007). Human rights and development: The case of local government transformation in South Africa. Retrieved from http://onlinelibrary.wiley.com/doi/10.1002/pad.449/full (accessed on May 17,2016).

94. Walde, T. (2002). Mining law reform in South Africa. Minerals \& Energy, 17(10).

95. Warner, K., Hamza, M., Oliver-Smith, A., Renaud, R., Julca, A. (2010). Climate change, environmental degradation and migration. Retrieved from https://link.springer.com/article/10.1007/s11069-009-9419-7

96. White, R. (2013). Resource extraction leaves something behind: Environmental justice and mining. International Journal for Crime, Justice and Social. Retrieved from https://www.crimejusticejournal.com/article/view/90 (accessed December 22, 2016).

97. Witze, A., Kanipe, J. (2015). Island on fire: the extraordinary story of a forgotten volcano that changed the world.

98. Wolfgang, F. (2003). Water control and mining grouting a South African historical perspective.

99. Yang, X., Zhang, K., Jia, L., Ci, L. (2002). Desertification assessment in China: An overview.

100.Yu, M. H., Tsunoda, H., Tsunoda, M. (2011). Environmental toxicology: biological and health effects of pollutants. Retrieved from https://books.google.co.za/books?hl=en\&lr=\&id=zMCiWZiuTJsC\&oi=fnd\&pg=PP1\&dq= PFn1YX0W0FZo1dSRtvvNPdc\#v=onepage\&q\&f=false (accessed on December 17,2016). 